\title{
Transition from anatomy school to the operating theatre for strabismus surgeons
}

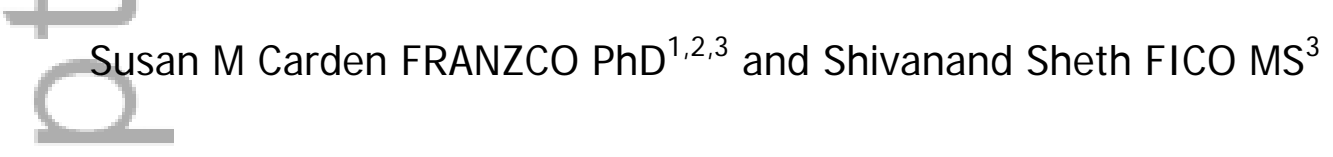

1. Department of Ophthalmology, Royal Children's Hospital, Melbourne, Australia

2. Department of Paediatrics, University of Melbourne, Melbourne, Australia

3. Royal Victorian Eye and Ear Hospital, Melbourne, Australia

Correspondence: Dr Susan Carden, Department of Ophthalmology, Royal Children's Hospital, Melbourne, Australia

Email:smcarden@aol.com

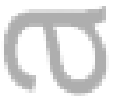

Received 10 J an 2016; accepted 1 May 2016

Conflict of interest: None

Funding sources: None

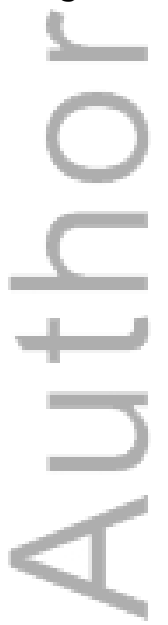

This is the author manuscript accepted for publication and has undergone full peer review but has not been through the copyediting, typesetting, pagination and proofreading process, which may lead to differences between this version and the Version of Record. Please cite this article as doi: $10.1111 /$ ceo.12779

This article is protected by copyright. All rights reserved. 
Ophthalmic trainee surgeons performing recessions on virgin extraocular horizontal muscles appear to gain great satisfaction at seeing clean, bare muscles, stripped of their Tenon's capsule.

In order to strip a muscle and lay it bare, a variety of instruments are employed that range from sharp scissors to blunt tools such as cotton buds. Tenon's capsule may be stretched, torn, chopped, cut, pulled and usually pushed aside. The general aim of junior trainee surgeons appears to be to remove any apparently unwanted Tenon's capsule so that a good length of bare, naked muscle surface is clearly exposed.

Stripping the muscle bare may have some advantages. First, it may be easier to see that the entire muscle has been hooked and not split. Secondly, clearing the Tenon's capsule from the conjunctival surface of the muscle may allow good visualization ensuring that actual muscle fibres have been secured. Thirdly, clearing Tenon's capsule from the scleral surface of the muscle might aid more secure muscle reattachment to the sclera, and a consequent decreased chance of muscle slippage. Nevertheless, it is important to remember that Tenon's capsule has important functions: it forms a protective sheath around extraocular muscles; it compartmentalises the eye; it forms intermuscular septa, and; it houses an intricate muscle pulley system. ${ }^{1}$

Thus, excessive dissection of the anterior part of Tenon's capsule exposes extraconal fat and risks disruption of the pulleys of the rectus muscles. ${ }^{2}$ However, minimally dissecting Tenon's capsule just a couple of millimetres at the insertion of the muscle (figure 1 ) is adequate to perform successful strabismus surgery. We recommend that trainees carefully dissect Tenon's capsule free from the overlying conjunctiva, and from the underlying sclera, while not stripping it from the muscle itself. This careful dissection will avoid the potential of any limitation of posterior retraction of recessed muscles that may be caused by Tenon's capsule. Similarly, concerns of bulging of the conjunctiva due to it being pulled anteriorly by Tenon's capsule during resections or plications are avoided. 
Wound closure may be slightly more difficult, especially with resections or plications, where Tenon's capsule may be anteriorly displaced. However, during closure, trimming the strands of excess Tenon's capsule is sufficient enough to complete wound closure, without disrupting it over the muscle surface.

Although no specific data is available, we believe that preservation of Tenon's capsule aids in prevention of muscle adherence to the overlying conjunctiva. This helps to prevent restrictive strabismus problems at a later date, and also makes dissection easier if further strabismus surgery is ever required. In general, it is important to retain as much of the anatomy of the tissues surrounding the extraocular muscle being operated on, as possible. ${ }^{3}$

How is this message transmitted to the many surgeons who consider that two muscle horizontal surgery is something easy for new trainees and generalist ophthalmologists to perform, and not trained strabismus surgeons? The anatomy lessons from cadavers in medical school are important but the treatment of the Tenon's capsular tissue is entirely different in a living patient. Tenon's capsule is an important structure within which muscles enjoy residing.

\section{REFERENCES}

1. Demer J L. Pivotal role of orbital connective tissues in binocular alignment and strabismus: The Friedenwald lecture. Investig Ophthalmol Vis Sci. 2004;45(3): 729-738. doi:10.1167/iovs.03-0464.

2. Wright KW. The fat adherence syndrome and strabismus after retina surgery. Ophthalmology. 1986;93(3):411-415.

http://www.ncbi.nlm.nih.gov/pubmed/3703512.

3. Mojon, D.S. (2014). Review: minimally invasive strabismus surgery. Eye, 29(2), 225-233. doi:10.1038/eye.2014.281 


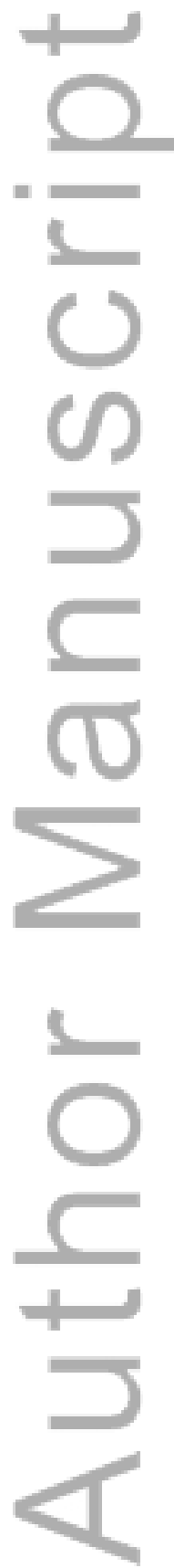

This article is protected by copyright. All rights reserved. 


\section{FIGURE LEGEND}

Figure 1: Figure demonstrating preservation of Tenon's capsule over the extraocular muscle surface with minimal dissection just at the insertion

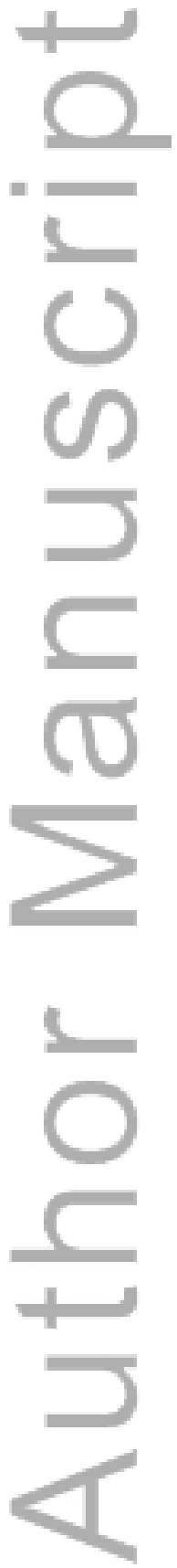



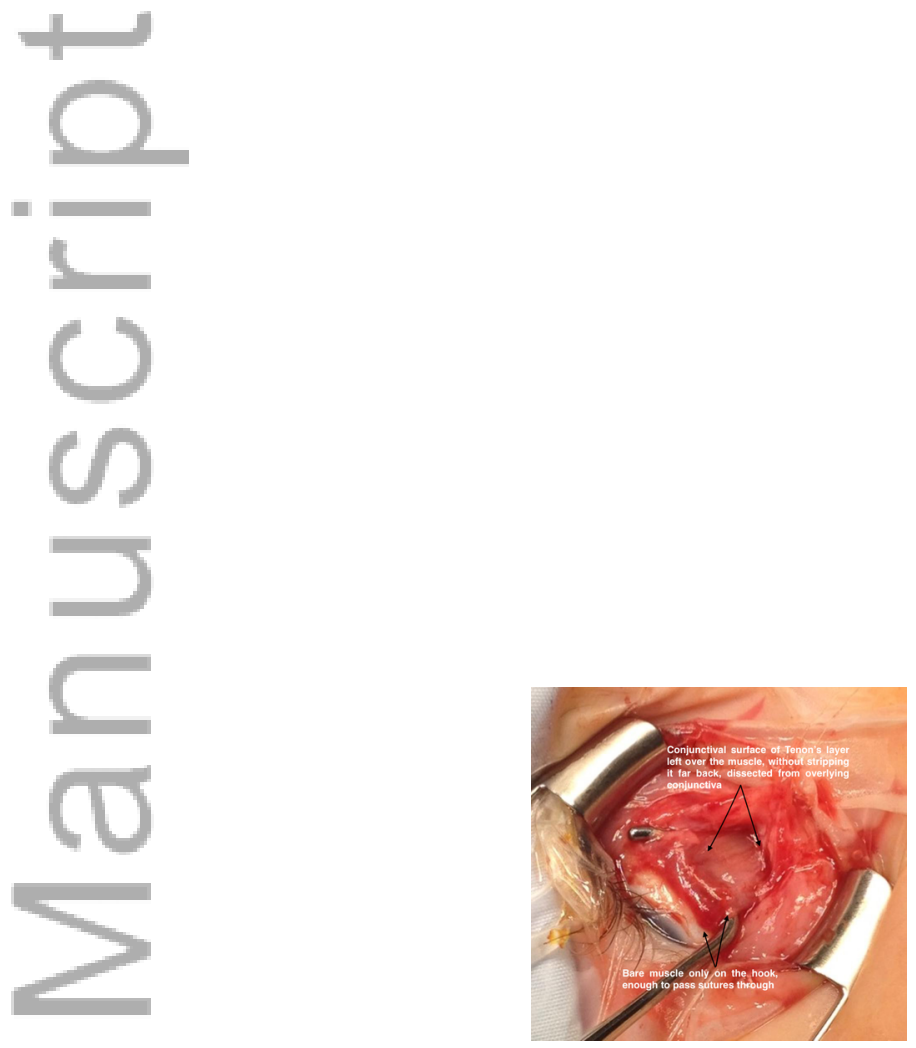

CEO_12779_F1.tiff

This article is protected by copyright. All rights reserved. 


\section{University Library}

\section{- M M N E R VA A gateway to Melbourne's research publications}

Minerva Access is the Institutional Repository of The University of Melbourne

Author/s:

Carden, SM;Sheth, S

Title:

Transition from anatomy school to the operating theatre for strabismus surgeons

Date:

2016-12-01

Citation:

Carden, S. M. \& Sheth, S. (2016). Transition from anatomy school to the operating theatre for strabismus surgeons. CLINICAL AND EXPERIMENTAL OPHTHALMOLOGY, 44 (9), pp.854-855. https://doi.org/10.1111/ceo.12779.

Persistent Link:

http://hdl.handle.net/11343/291463 